\title{
Thermoanalytical studies of carbamazepine: hydration/ dehydration, thermal decomposition, and solid phase transitions
}

\author{
Mônia Aparecida Lemos Pinto, Beatriz Ambrozini*, Ana Paula Garcia Ferreira, \\ Éder Tadeu Gomes Cavalheiro
}

\author{
Department of Chemistry and Molecular Physics, Institute of Chemistry of São Carlos, \\ University of São Paulo, São Carlos, SP, Brazil
}

\begin{abstract}
Carbamazepine (CBZ), a widely used anticonvulsant drug, can crystallize and exhibits four polymorphic forms and one dihydrate. Anhydrous CBZ can spontaneously absorb water and convert to the hydrate form whose different crystallinity leads to lower biological activity. The present study was concerned to the possibility of recovering the hydrated form by heating. The thermal behavior of spontaneously hydrated carbamazepine was investigated by TG/DTG-DTA and DSC in dynamic atmospheres of air and nitrogen, which revealed that the spontaneous hydration of this pharmaceutical resulted in a Form III hydrate with 1.5 water molecules. After dehydration, this anhydrous Form III converted to Form I, which melted and decomposed in a single event, releasing isocyanic acid, as shown by evolved gas analysis using TG-FTIR. Differential scanning calorimetry analyses revealed that Form III melted and crystallized as Form I, and that subsequent cooling cycles only generated Form I by crystallization. Solid state decomposition kinetic studies showed that there was no change in the substance after the elimination of water by heating to $120^{\circ} \mathrm{C}$. Activation energies of $98 \pm 2$ and $93 \pm 2 \mathrm{~kJ} \mathrm{~mol}^{-1}$ were found for the hydrated and dried samples, respectively, and similar profiles of activation energy as a function of conversion factor were observed for these samples.
\end{abstract}

Uniterms: Carbamazepine/thermal analysis. Polymorphism. Hydrate. Dehydration.

A carbamazepina (CBZ) é um anticonvulsivante frequentemente utilizado no Brasil e em vários países. Ela apresenta quatro formas polimórficas e um diidrato. Todas as formas são ativas farmacologicamente, porém a Forma III é a preferível do ponto de vista farmacêutico, em função de suas propriedades físicoquímicas. Entretanto, essa forma é altamente higroscópica, podendo converter-se ao diidrato, menos ativo biologicamente. Nesse trabalho propõe-se avaliar o comportamento térmico da forma hidratada, visando à recuperação da forma ativa, por aquecimento. Para tanto, foi feito um estudo do comportamento térmico por TG/DTG-DTA e DSC em atmosfera dinâmica de ar e nitrogênio, que evidenciou hidratação espontânea da Forma III, gerando um hidrato contendo 1,5 moléculas de água. Essa forma sofre desidratação, seguida de fusão e conversão para a Forma I. Segue-se a decomposição em uma única etapa, na qual ocorre liberação do ácido isociânico, conforme análise de gases evolvidos, por termogravimetria acoplada ao infravermelho (TG-FTIR). Estudos por calorimetria exploratória diferencial mostraram que a Forma III se funde e se cristaliza imediatamente na Forma I, durante o aquecimento. A Forma I também se funde e ciclos de aquecimento/resfriamento posteriores evidenciaram que a substância se cristaliza apenas na Forma I por resfriamento. Estudos cinéticos da decomposição, em estado sólido, mostraram que não há alteração na substância pela eliminação da água por aquecimento, sendo determinados valores de energia de ativação da ordem de $98 \pm 2$ e $93 \pm 2 \mathrm{~kJ} \mathrm{~mol}^{-1}$, respectivamente, para a amostra hidratada e submetida à secagem, assim como perfis semelhantes nas curvas de energia de ativação em função do fator de conversão.

Unitermos: Carbamazepina/análise térmica. Polimorfismo. Hidratação. Desidratação.

\footnotetext{
*Correspondence: B. Ambrozini. Departamento de Química e Física Molecular, Instituto de Química de São Carlos, Universidade de São Paulo. Av. Trabalhador São-Carlense, 400, Caixa Postal 780, 13560-970, São Carlos, SP, Brasil. E-mail: biaambro@gmail.com
} 


\section{INTRODUCTION}

Carbamazepine (CBZ) (Figure 1), 5H-dibenz$(b, f)$ azepine-5-carboxamide, is a white or almost white crystalline powder that is used as a first-generation anticonvulsant drug to treat epilepsy, trigeminal neuralgia, manic-depressive illness, and explosive aggression. The efficacy of CBZ was confirmed in the 1960s, when it was launched onto the commercial market (Liu et al., 2008; Ambrogi et al., 2007; Krongauz et al., 2007). When administered by the oral route, it presents a slow rate of absorption, which requires the use of a relatively large dose (Rose, Johnson, 1997; Dalkara, Karakurt, 2012).

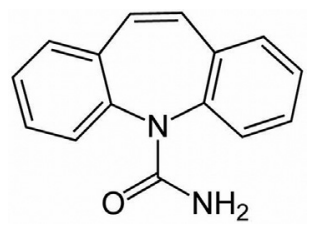

FIGURE 1 - Structure of carbamazepine.

At least four polymorphs and a dehydrate, as well as other solvates of CBZ, have been described in the literature (Qu, Louhi-Kultanen, Kallas, 2006; O’Mahony et al., 2012). The melting points of the four polymorphs have been reported to be in the range $175-190{ }^{\circ} \mathrm{C}$ (Gosselin et al., 2003). The most stable known anhydrous form under room conditions is Form III. It is also known that in a humid environment, the anhydrates take up water and convert to the hydrates (Liu, Dang, Wei, 2012). Forms I and III of the drug constitute an enantiotropic pair, whose relative thermodynamic stability changes at $70^{\circ} \mathrm{C}$. Below this temperature, Form III is most stable, while above this temperature, Form I becomes more stable (McGregor et al., 2004; Behme, Brook, 1991; Lowes et al., 1987).

Hydrates are molecular complexes containing water molecules incorporated (usually stoichiometrically) into their crystal lattices (Han, Suryanarayanan, 1997). The water molecules of a hydrate can be released from the crystal lattice under drying conditions, such as heating. Most hydrate-anhydrate transformations are reversible and are influenced by temperature, relative humidity, particle size, and surface area. It is possible for the transformation to occur at room temperature as well as during drug processing, transportation, and storage. Evaluation of the hydration and dehydration behavior of pharmaceutical substances is important for the development of stable formulations, because the anhydrous and hydrated forms of a drug can show differences in their physicochemical characteristics. Properties including heat capacity, density, crystal structure, chemical stability, hygroscopicity, powder flow, and dissolution rate ultimately affect the bioavailability of a drug (Solon et al., 2010; Ono et al., 2002; McMahon et al., 1996; Qu, Louhi-Kultanen, Kallas, 2006).

In work by Xu et al. (2011), the pharmacokinetics of the polymorphic Forms I and III and the dihydrate of carbamazepine were evaluated in mice and compared to the behavior of these substances in dogs and humans. The absorption of Form III in mice was very similar to that observed for humans, and the pharmacokinetic properties and stability of the polymorph proved to be satisfactory. The P-monoclinic form Form III is considered more suitable for commercial formulations of carbamazepine, due to it higher bioavailability, compared to the other polymorphs.

Knowledge of the interconversion of the various polymorphic forms of $\mathrm{CBZ}$ is needed because the performance of this drug depends on the form that is present (Krahn, Mielck, 1987; Rustichelli et al., 2000; Kobayashi et al., 2000; Cabeza et al., 2007). However, information concerning the hydration/dehydration processes involved remains scarce.

The most active form of carbamazepine is its anhydrous Form III, which is highly hygroscopic. It is therefore important to investigate the stability and thermal behavior of the spontaneously hydrated form, the regeneration of the active anhydrous Form III, and the polymorphic conversions involved in this process. Thermal analyses employing DSC and TG-DTA have been used previously to gain insight into the thermal behaviors of hydrated CBZ and Form III (Liu, Dang, Wei, 2012; McGregor et al., 2004; Han, Suryanarayanan, 1997).Although Liu and co-workers (Liu, Dang, Wei, 2012) recently described the thermal behavior of hydrated carbamazepine, considering dehydration, degradation, and kinetic data, to the best of our knowledge there have been no detailed studies of the degradation of CBZ and the formation of volatile products using TG-FTIR and DSC with heat-cool-heat cycles in order to elucidate the crystallization processes.

This work therefore describes an investigation of the thermal behavior of the spontaneously hydrated CBZ Form III, in terms of the dehydration process, formation of volatile degradation products, polymorphic interconversion, and the kinetics of dehydration and decomposition, in order to evaluate the possibility of recovering carbamazepine that becomes hydrated due to its storage under unsuitable conditions.

\section{MATERIAL AND METHODS}

Carbamazepine (pharmaceutical grade $\geq 99.0 \%$, Sigma-Aldrich) was used without further purification and 
was stored under room conditions $\left(\mathrm{T}=18-25^{\circ} \mathrm{C}\right.$; humidity $=40-80 \%$ ) for one year.

Simultaneous TG/DTG and DTA measurements were carried out using a Model SDT-Q600 analyzer (TA Instruments) with alumina sample holders $(90 \mu \mathrm{L})$. The sample $6 \mathrm{mg}$ was heated to a final temperature of $800^{\circ} \mathrm{C}$ at a rate of $10^{\circ} \mathrm{C} \mathrm{min}^{-1}$, under a flow of air $\left(100 \mathrm{~mL} \mathrm{~min}^{-1}\right)$. Temperature calibration of the apparatus employed a zinc standard, as recommended by the manufacturer.

Thermogravimetry (TG) was used to study the kinetics of CBZ thermal dehydration and decomposition, employing the Flynn-Wall-Ozawa model (Flynn, Wall, 1996; Ozawa, 1970; Doyle, 1962). For the kinetic studies using spontaneously hydrated $\mathrm{CBZ}$ and samples of $\mathrm{CBZ}$ dried at $120^{\circ} \mathrm{C}, \mathrm{TG}$ analyses were performed at heating rates of were performed at heating rates of 2.5, 5.0, 10.0, and $15.0 \mathrm{~min}^{-1}$, under the same conditions described above. Guinesi et al. (2006) provided a detailed description of the theory and equations involved in this method. Data analysis was performed using Thermal Specialty Library v.1.4 software (TA Instruments).

DSC curves were obtained using sample masses of $\sim 2 \mathrm{mg}$, placed in covered aluminum pans with a central pinhole $(\phi=0.7 \mathrm{~mm})$ in the lid. The heating rate was $10^{\circ} \mathrm{C}$ $\mathrm{min}^{-1}$, in a temperature interval of -40 to $194^{\circ} \mathrm{C}$, under a flow of $\mathrm{N}_{2}$ at $25 \mathrm{~mL} \mathrm{~min}^{-1}$. The curves were obtained in heat-cool-heat cycle mode. A DSC-Q10 unit controlled by Thermal Advantage for Q-Series software (both from TA instruments) was used in these analyses. Calibrations of the equipment for temperature and enthalpy measurements were performed using indium metal ( $99.99 \%$ purity) as a standard, according to the manufacturer's manual.

The TGA-FTIR experiments were performed using a TG-DSC 851 analyzer (Mettler-Toledo) coupled to a Nicolet iS10 FTIR spectrometer. The transfer line consisted of a stainless steel tube $(120 \mathrm{~cm}$ length, $2 \mathrm{~mm}$ internal diameter), heated at a constant temperature of $200^{\circ} \mathrm{C}$. The FTIR measurements employed a DTGS detector with a gas cell heated at a constant temperature of $250{ }^{\circ} \mathrm{C}$. The interferometer and the gas cell compartments were purged with highly purified $\mathrm{N}_{2}$ at a flow rate of $50 \mathrm{~mL} \mathrm{~min}^{-1}$, and the heating rate was $10^{\circ} \mathrm{C} \mathrm{min}^{-1}$. The TG-DSC analyses were performed using a sample mass of $12 \mathrm{mg}$ in alumina crucibles.

The carbon, hydrogen, and nitrogen contents of the samples were determined by elemental analysis, using a Model EA 1110 CHNS-O analyzer (CE Instruments).

$\mathrm{X}$-ray powder diffraction patterns were obtained using a Rotaflex RU-200B X-ray diffractometer (Rigaku) employing $\mathrm{CuK}_{\alpha}$ radiation $(\alpha=1.541 \AA)$ and settings of $50 \mathrm{kV}$ and $100 \mathrm{~mA}$.

\section{RESULTS AND DISCUSSION}

As commonly occurs with polymorphic systems, there has been much confusion about the naming of CBZ polymorphs. For the purposes of this article and for clarity, we have adopted the nomenclature described by Grzesiak et al. (2003).

\section{Thermal behavior of spontaneously hydrated CBZ and anhydrous form III}

In an air atmosphere, the thermal decomposition of spontaneously hydrate $\mathrm{CBZ}$ proceeds in three steps of mass loss, between $19{ }^{\circ} \mathrm{C}$ and $332{ }^{\circ} \mathrm{C}$, following the TG/ DTG curves shown in Figure 2.

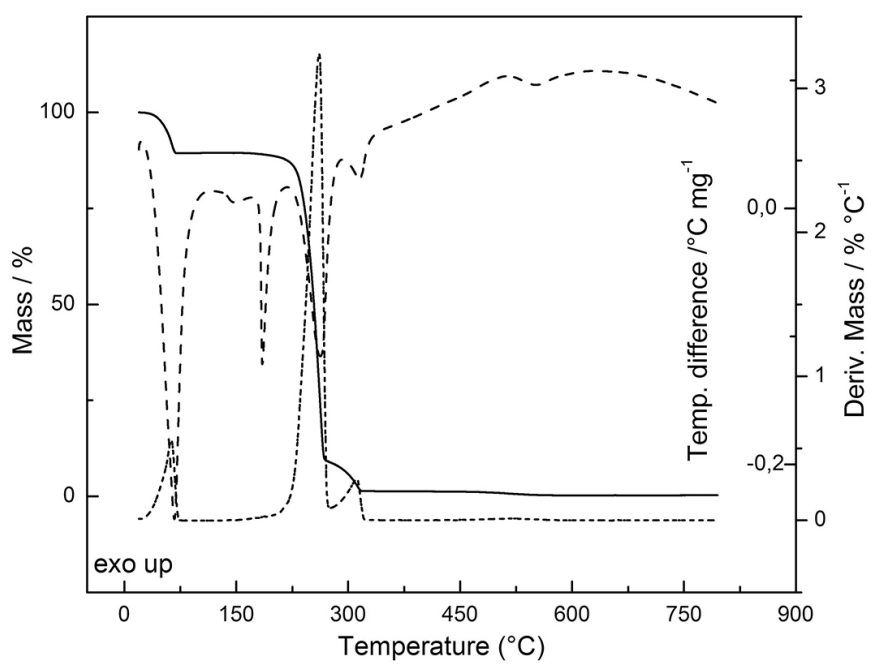

FIGURE 2 - TG (solid line), DTG (short dashed line), and DTA (dashed line) curves for carbamazepine heated in a dynamic air atmosphere $(\mathrm{m}=6.186 \mathrm{mg})$.

The first mass loss, which occurred in a single thermal event in the range $19-74{ }^{\circ} \mathrm{C}$, corresponded to dehydration, with the loss of 1.5 water molecules. The experimental and calculated mass losses were $10.61 \%$ and $10.26 \%$ respectively. In order to confirm the existence of 1.5 molecules of hydration water in the sample of carbamazepine analyzed, it was subjected to elemental analysis (considering the contents of $\mathrm{C}, \mathrm{H}$, and $\mathrm{N}$ ), before and after heating to $120^{\circ} \mathrm{C}$. The TG results showed that the first step of mass loss was completed and that no further decomposition occurred. Table I presents the comparative data obtained for the anhydrous sample and samples containing 1.5 and 2.0 water molecules.

It could be concluded that after heating, the anhydrous form was regenerated, without decomposition and preserving the original stoichiometry. The results also 
TABLE I - Experimental (exp) and calculated (calc) elemental composition of carbamazepine

\begin{tabular}{lccc}
\hline \multirow{2}{*}{ Carbamazepine } & \multicolumn{3}{c}{ Element / \%, $\exp$ (calc) } \\
\cline { 2 - 4 } & $\mathbf{C}$ & $\mathbf{H}$ & $\mathbf{N}$ \\
\hline $\mathrm{C}_{15} \mathrm{H}_{12} \mathrm{~N}_{2} \mathrm{O}$ (anhydrous) & $76.6(76.1)$ & $5.2(5.1)$ & $12.1(11.8)$ \\
$\mathrm{C}_{15} \mathrm{H}_{12} \mathrm{~N}_{2} \mathrm{O} .1 .5 \mathrm{H}_{2} \mathrm{O}$ & $67.7(68.4)$ & $7.1(6.3)$ & $10.7(10.6)$ \\
$\mathrm{C}_{15} \mathrm{H}_{12} \mathrm{~N}_{2} \mathrm{O} .2 \mathrm{H}_{2} \mathrm{O}$ & $67.7(66.1)$ & $7.1(5.9)$ & $10.7(10.2)$ \\
\hline
\end{tabular}

showed that the spontaneously hydrated sample contained only 1.5 molecules of hydration water per mol of CBZ, despite the fact that the literature suggests the existence of a dehydrate (Kobayashi et al., 2000). This can be explained by the occurrence of a spontaneous partial hydration, which then remained constant under ambient room conditions.

After dehydration, the second mass loss (79.8\%), between 198 and $275^{\circ} \mathrm{C}$, was due to thermal decomposition of the anhydrous drug. The third mass loss $(8.15 \%)$ in the range $275-332{ }^{\circ} \mathrm{C}$, was attributed to the decomposition of residual carbonaceous material. A very small mass loss $(1.2 \%)$ in the range $500-550{ }^{\circ} \mathrm{C}$ was related to the combustion of residual carbon.

The DTA curve obtained using an air atmosphere (Figure 2) exhibited six peaks and agreed with (and extended) the thermal data obtained from the TG/DTG curves. The first endothermic peak, at $67.1^{\circ} \mathrm{C}$, was attributed to dehydration, and the second endothermic peak, at $147.8^{\circ} \mathrm{C}$, was attributed to melting of the anhydrous polymorphic Form III (Liu, Dang, Wei, 2012; Kobayashi et al., 2000). The exothermic peak at $174.4{ }^{\circ} \mathrm{C}$ and the sharp endothermic peak at $184.9^{\circ} \mathrm{C}$ corresponded to crystallization and to melting of the polymorphic Form I, respectively. The decomposition was accompanied by two endothermic peaks, at 262.4 and $314.8^{\circ} \mathrm{C}$, followed by an exothermic peak (at $530^{\circ} \mathrm{C}$ ) attributed to combustion of the residual carbonaceous material.

The DSC curves obtained for the spontaneously hydrated carbamazepine using successive heating-coolingheating cycles are presented in Figure 3. During the first heating cycle, a broad endothermic peak appeared at $70.1{ }^{\circ} \mathrm{C}$ $\left(\mathrm{T}_{\text {onset }}=58.5^{\circ} \mathrm{C}\right)$, corresponding to dehydration of the sample, in agreement with the TGA/DTG curve for the drug.

With further heating, a second endothermic signal was observed at $\sim 173.5^{\circ} \mathrm{C}\left(\mathrm{T}_{\text {onset }}=158.9^{\circ} \mathrm{C}\right)$, corresponding to the melting of Form III of carbamazepine, which immediately crystallized as Form I, represented by the exothermic signal at $174.7^{\circ} \mathrm{C}\left(\mathrm{T}_{\text {onset }}=173.8^{\circ} \mathrm{C}\right)$. This was in agreement with the findings of Grzesiak et al. (2003).

Finally, a sharp endothermic peak at $191.3{ }^{\circ} \mathrm{C}$ $\left(\mathrm{T}_{\text {onset }}=190.6^{\circ} \mathrm{C}\right)$ corresponded to the melting of Form I (Grzesiak et al., 2003).

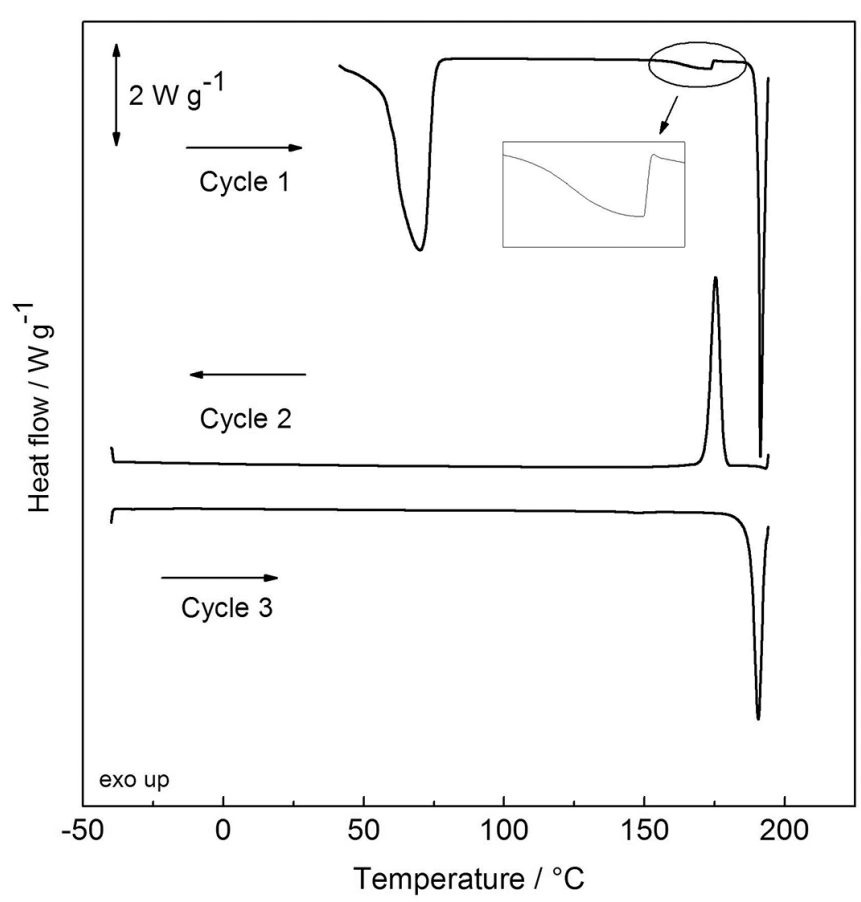

FIGURE 3 - Heat-cool-heat DSC curves for carbamazepine, obtained under an $\mathrm{N}_{2}$ atmosphere $(\mathrm{m}=2.000 \mathrm{mg})$.

During the cooling step, a single thermal event was observed, represented by an exothermic peak at $175.3^{\circ} \mathrm{C}\left(\mathrm{T}_{\text {onset }}=178.2{ }^{\circ} \mathrm{C}\right)$, which was probably related to crystallization of the sample. Subsequent cooling to $-40{ }^{\circ} \mathrm{C}$ did not reveal any other thermal events.

During the second heating step, no thermal event was observed in the -40 to $170{ }^{\circ} \mathrm{C}$ range. However, there was a sharp endothermic peak at $190.5^{\circ} \mathrm{C}$ $\left(\mathrm{T}_{\text {onset }}=187.8^{\circ} \mathrm{C}\right)$ that coincided with the peak observed in the first heating cycle and was therefore related to the melting of Form I.

The enthalpy changes measured for thermal events observed during the heating-cooling-heating cycles can be summarized as follows:

Cycle 1: Dehydration of Form III: $\Delta H=74.35 \mathrm{~kJ} \mathrm{~mol}^{-1}$ Melting of Form I: $\quad \Delta H=27.97 \mathrm{~kJ} \mathrm{~mol}^{-1}$

Cycle 2: Crystallization of Form I: $\Delta H=-22.37 \mathrm{~kJ} \mathrm{~mol}^{-1}$ Cycle 3: Melting of Form I: $\quad \Delta H=23.44 \mathrm{~kJ} \mathrm{~mol}^{-1}$ 
Due to the fact that the carbamazepine Form III melting endotherm was followed by a subsequent Form I recrystallization exotherm, resolution of these two overlapping events was not possible using DSC. Consequently, it was not possible to measure the enthalpy changes involved in the Form III melting endotherm or the Form I crystallization in the first cycle (McGregor et al., 2004).

The melting of Form III followed by recrystallization of Form I was confirmed by heating the sample to $175^{\circ} \mathrm{C}$ in a glass tube and visually observing the changes.

In summary, it could be concluded that the sample used in this work was the spontaneously hydrated Form III of carbamazepine. When heated, this dehydrated to the anhydrous Form III in the solid phase, which then melted and converted to Form I by recrystallization. The Form I solid also showed melting, at a slightly higher temperature. Successive cooling and heating resulted in Form I in the solid and liquid phases, respectively. The present work therefore revealed that Form I was preferentially produced by cooling.

In order to confirm the phase transitions observed by DSC, a sample of the spontaneously hydrated $\mathrm{CBZ}$ was heated in an oven at $120^{\circ} \mathrm{C}$ for $30 \mathrm{~min}$. A second sample was heated at $196{ }^{\circ} \mathrm{C}$ for $30 \mathrm{~min}$. X-ray diffraction analysis of the solids obtained after these thermal treatments revealed both were crystalline, as shown by the diffractograms (Figure 4). Specific peaks for spontaneously hydrated CBZ were observed at $2 \theta=8.78,12.15,18.76$, and 19.37 (Figure 4a). Form III showed diagnostic peaks at $2 \theta=15.36,19.36,24.82$, and 27.45 (Figure 4b). Specific peaks for Form I occurred at $2 \theta=7.93,9.40,12.22$, and 19.8 (Figure $4 \mathrm{c}$ ).

Although the results were consistent with those described in the literature (Rustichelli et al., 2000; Kobayashi et al., 2000; Grzesiak et al., 2003), they revealed that CBZ Form III was converted to CBZ Form I significantly faster than previously reported. In earlier work, the times required were $9 \mathrm{~h}$ at $140{ }^{\circ} \mathrm{C}$ (Javadzadeh et al., 2009), $4 \mathrm{~h}$ at $140{ }^{\circ} \mathrm{C}$ (McMahon et al., 1996), and $2 \mathrm{~h}$ at $170{ }^{\circ} \mathrm{C}$ (Behme, Brook, 1991). This time reduction included consideration of the melting of CBZ Form I, followed by its crystallization.

\section{Evolved gas analysis}

The gaseous products released during thermal decomposition of the CBZ hydrate were monitored by FTIR. In these experiments, the sample was again submitted to thermogravimetry, but under a dynamic nitrogen atmosphere. The resulting TG curve (not shown) was similar to that obtained in air. The FTIR spectra of the gaseous products evolved during the decomposition of the drug are presented in Figure 5.

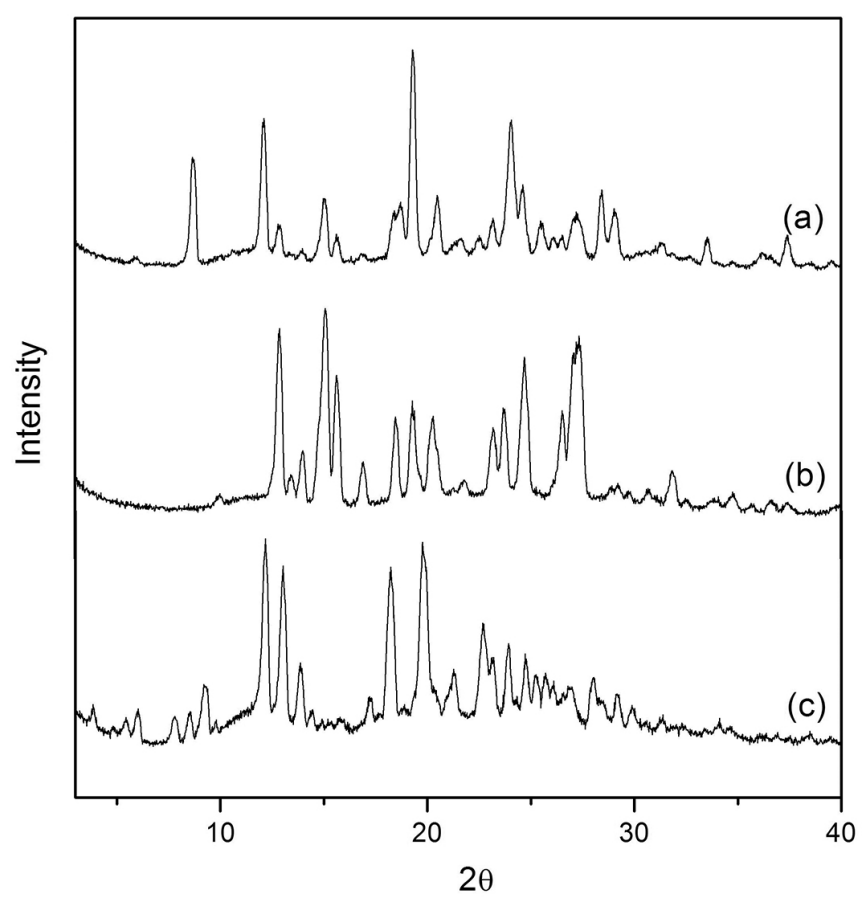

FIGURE 4 - X-ray powder diffraction patterns for carbamazepine: (a) hydrated, (b) Form III, and (c) Form I.

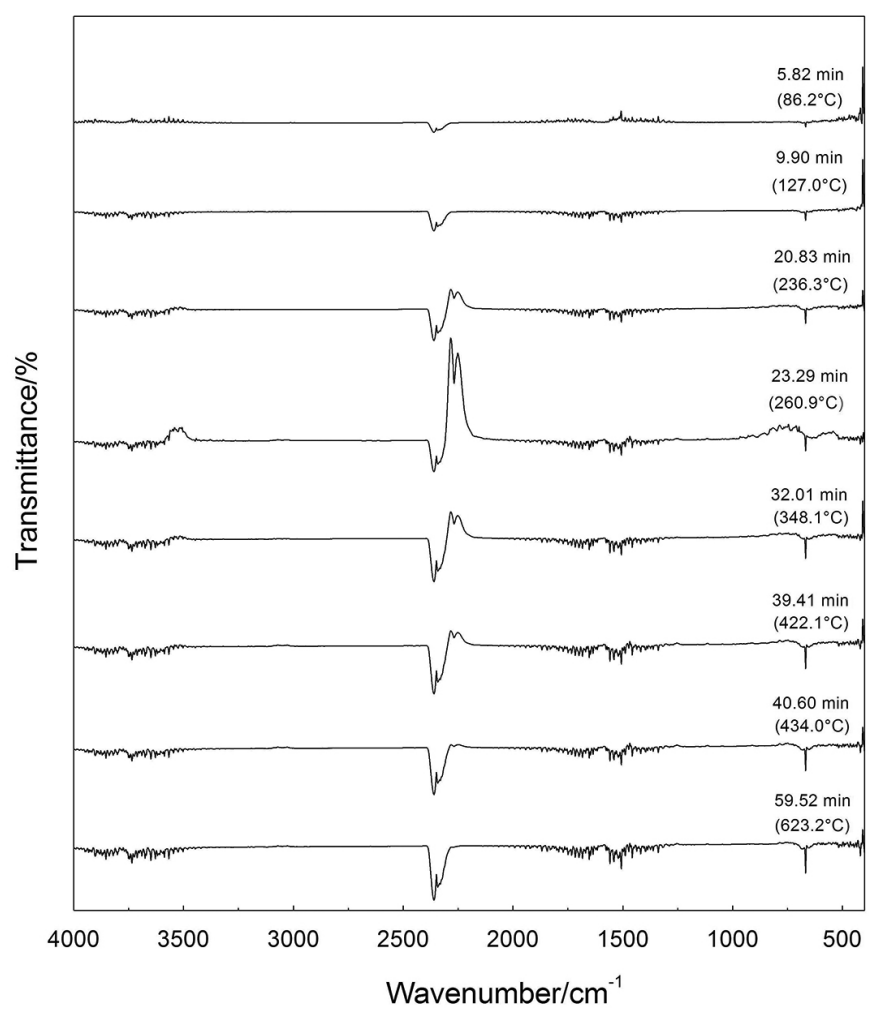

FIGURE 5 - Infrared spectra of the gases released during the decomposition of carbamazepine in an $\mathrm{N}_{2}$ atmosphere. 
The FTIR spectra of the gaseous products evolved during the thermal decomposition of carbamazepine were indicative of the release of water, with intense evolution at $5.82 \mathrm{~min}\left(86.2^{\circ} \mathrm{C}\right)$ associated with positive absorbance signals in the $3500-4000 \mathrm{~cm}^{-1}$ and $1250-1750 \mathrm{~cm}^{-1}$ regions. Between $20.83 \mathrm{~min}\left(236.3{ }^{\circ} \mathrm{C}\right)$ and $40.60 \mathrm{~min}\left(434.0^{\circ} \mathrm{C}\right)$, the evolution of isocyanic acid could be clearly observed, with signals at 3400,2250 , and $1000-500 \mathrm{~cm}^{-1}$.

At the end of the experiment, at $59.52 \mathrm{~min}$ $\left(623.2^{\circ} \mathrm{C}\right)$, small signals corresponding to water and $\mathrm{CO}_{2}$ were observed, which could be explained by the decomposition of carbonized material due to oxidation by traces of oxygen in the carrier gas. The gas phase spectra of water, $\mathrm{CO}_{2}$, and isocyanic acid matched those from the spectral library (OMNIC v.8.0, 2008).

The TG/DTG, DTA, and DSC curves, together with the FTIR spectra of the volatile decomposition products, were used to propose a pathway for the thermal behavior of spontaneously hydrated carbamazepine, as shown in Figure 6.

Although the proposed thermal pathway suggests that the decomposition occurred with the elimination of isocyanic acid (HNCO) and iminostilbene $\left(\mathrm{C}_{14} \mathrm{H}_{11} \mathrm{~N}\right)$, only isocyanic acid could be positively identified in the evolved gas analysis using TG-FTIR. This could be explained by the condensation of iminostilbene, whose boiling point $\left(220^{\circ} \mathrm{C}\right)($ Chemical Book, 2012) is the same as the transfer line temperature utilized $\left(220^{\circ} \mathrm{C}\right)$. The release of iminostilbene must have occurred, because the mass loss was almost complete in the first degradation step.

\section{Thermal kinetics study}

The aim of this study was to evaluate possible changes in the thermodynamic parameters of the carbamazepine decomposition processes due to either spontaneous hydration or dehydration by heating. Activation energies $\left(E_{\mathrm{a}}\right)$ and pre-exponential factors $(\log \mathrm{A})$ were measured for the dehydration and decomposition steps of the spontaneously hydrated sample, as well as for the decomposition of the sample heated to $120^{\circ} \mathrm{C}$ (Table II). These values were obtained from the stable portions of the $\mathrm{E}_{\mathrm{a}}$ vs. $\alpha$ plots (Vyazovkin et al., 2011).

From the data shown in Table II, it could be concluded that the of activation energies and $\log$ A factors for both the spontaneously hydrated sample and the sample heated to $120^{\circ} \mathrm{C}$ were quite similar, confirming that these samples presented very similar characteristics. The TG

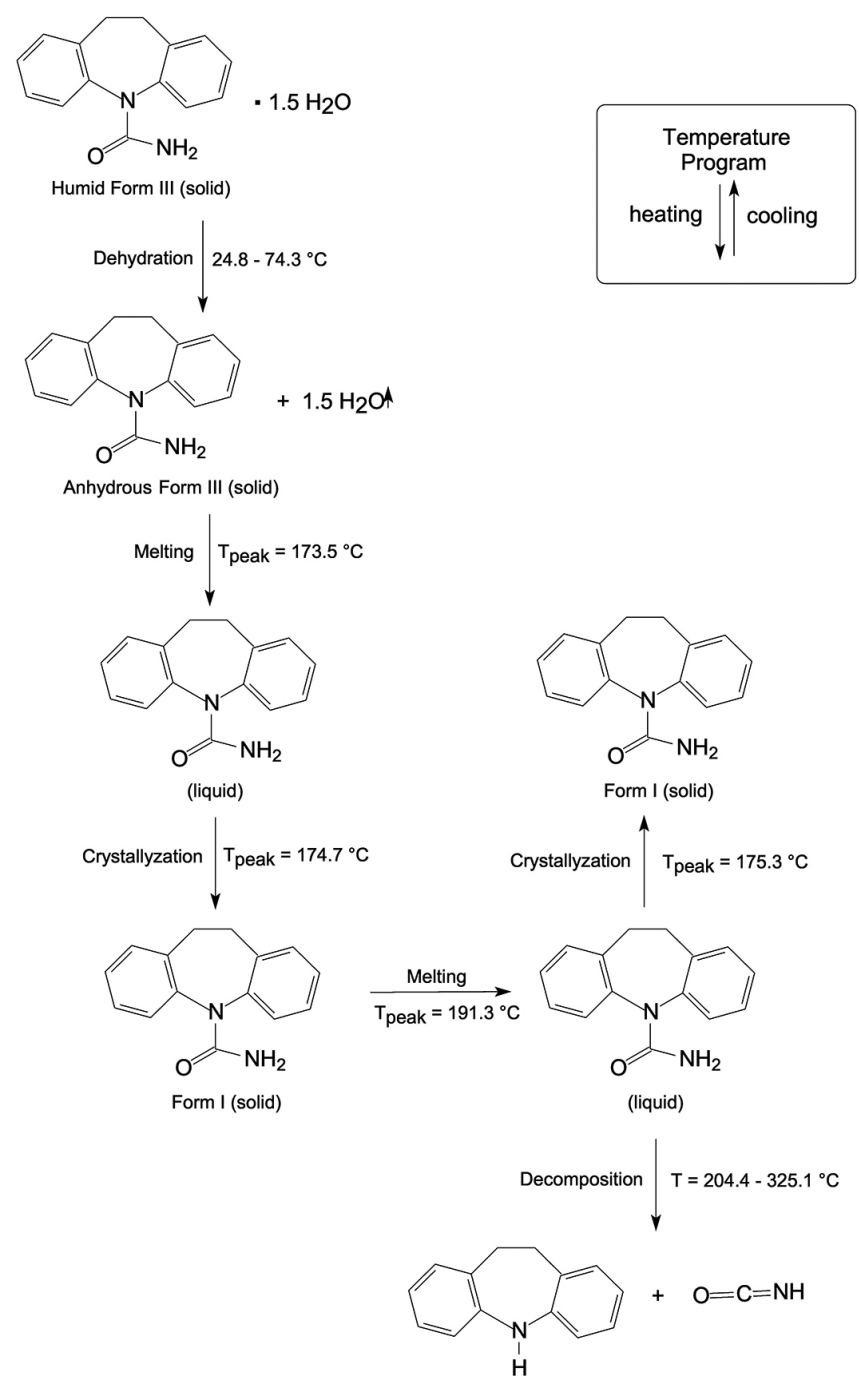

FIGURE 6 - Thermal pathway for the decomposition of carbamazepine.

TABLE II - Activation energies $\left(E_{\mathrm{a}}\right)$ and pre-exponential factors $(\log \mathrm{A})$ for hydrated and dried carbamazepine

\begin{tabular}{lccc}
\hline Sample & Event & $\begin{array}{c}E_{\mathrm{a}} / \\
\mathrm{kJ} \mathrm{mol}^{-1}\end{array}$ & $\begin{array}{c}\log \mathrm{A} / \\
\mathrm{min}^{-1}\end{array}$ \\
\hline CBZ 1.5 $\mathrm{H}_{2} \mathrm{O}$ & Dehydration & $73 \pm 2$ & $11.3 \pm 0.4$ \\
& Decomposition & $98 \pm 2$ & $9.3 \pm 0.1$ \\
\hline $\mathrm{CBZ}$ & Decomposition & $93 \pm 2$ & $8.6 \pm 0.1$ \\
\hline
\end{tabular}

curves obtained using different heating rates are presented in Figure 7.

\section{CONCLUSIONS}

The present investigation showed that Form III of anhydrous CBZ can become spontaneously hydrated, 

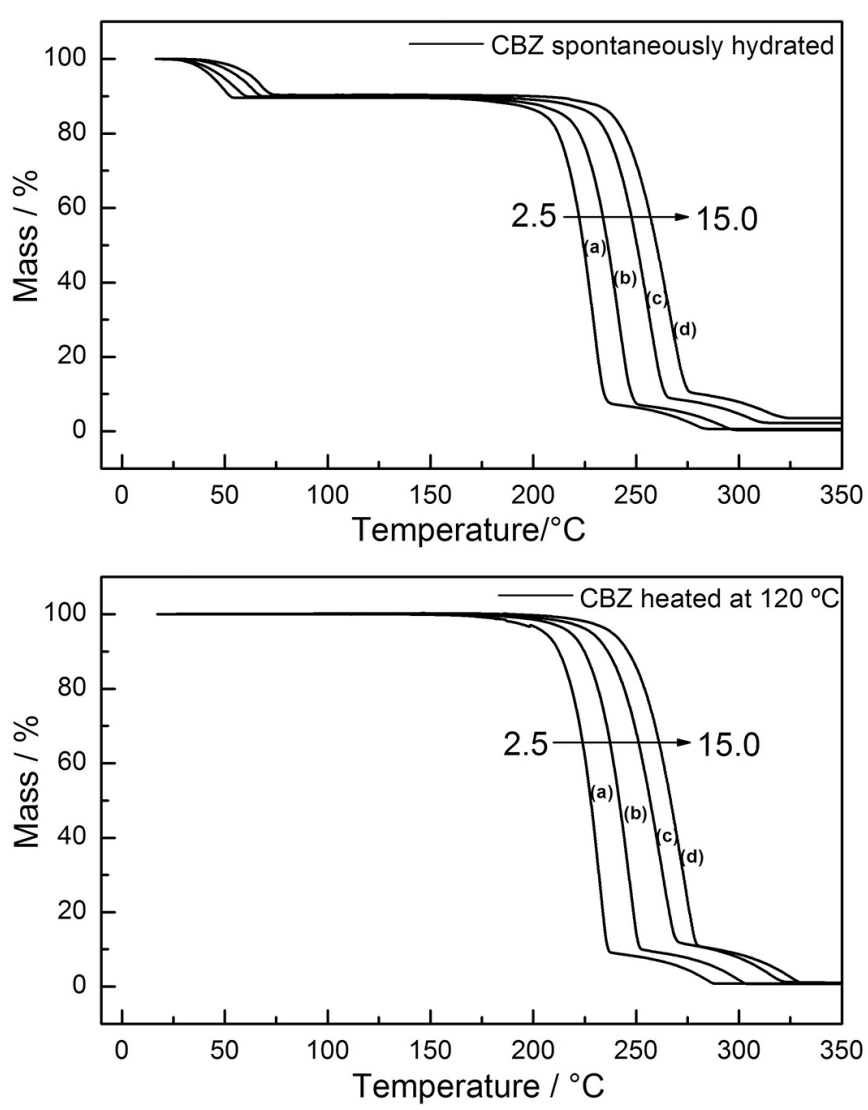

FIGURE 7 - TG curves for spontaneously hydrated CBZ and CBZ heated at $120^{\circ} \mathrm{C}$ in an $\mathrm{N}_{2}$ atmosphere, using different heating rates: (a) 2.5 ; (b) 5.0 ; (c) 10.0 ; (d) $15.0{ }^{\circ} \mathrm{C} \mathrm{min}{ }^{-1}$ $(\mathrm{m}=6.0 \mathrm{mg})$.

producing a 1.5 hydrate. The water molecules could be removed by heating the sample to $120^{\circ} \mathrm{C}$, without risk of decomposition of the active Form III. These findings were supported by the results of TG/DTG, DTA, X-ray diffraction, and thermal kinetics analyses.

A detailed pathway of the thermal behavior of the spontaneously hydrated sample is proposed, based on the TG-FTIR and DSC data and supported by X-ray diffraction analyses of the solids and the FTIR spectra obtained for the gases evolved during sample decomposition.

The melting of $\mathrm{CBZ}$ at temperatures near $200^{\circ} \mathrm{C}$ seems to indicate that Form I is most stable. Form I was formed preferentially by cooling, under the conditions used here; any subsequent conversion observed during the cooling-heating cycles occurred after Form I was obtained.

\section{ACKNOWLEDGEMENTS}

The authors thank the Brazilian agencies CNPq and FAPESP for financial support. We are also indebted to
Prof. Massao Ionashiro (IQ-UNESP, Brazil) for provision of the TG-FTIR facilities.

\section{REFERENCES}

AMBROGI, V.; PERIOLI, L.; MARMOTTINI, F.; ACCORSI, O.; PAGANO, C.; RICCI, M.; ROSSI, C. Role of mesoporous silicates on carbamazepine dissolution rate enhancement. Micropor. Mesopor. Mat., v.113, p.445-452, 2007.

BEHME, R.J.; BROOK, D. Heat of fusion measurement of a low melting polymorph of carbamazepine that undergoes multiple-phase changes during differential scanning calorimetry analysis. J. Pharm. Sci., v.80, p.986-990, 1991.

CABEZA, A.J.C.; DAY, G.M.; MOTHERWELL, W.D.S.; JONES, W. Solvent inclusion in form II carbamazepine. Chem. Commun., v.16, p.1600-1602, 2007.

CHEMICAL BOOK. Available at: <http://www.chemicalbook. com/ProductChemicalPropertiesCB8853392_EN.htm> Accessed on: 08 November 2012.

DALKARA, S.; KARAKURT, A. Recent progress in anticonvulsant drug research: strategies for anticonvulsant drug development and applications of antiepileptic drugs for non-epileptic central nervous system disorders. Curr. Top. Med. Chem., v.12, p.1033-1071, 2012.

DOYLE, C.D. Estimating isothermal life from thermogravimetric data. J. Appl. Polym. Sci., v.6, p.639-642, 1962.

FLYNN, J.H.; WALL, L.A. A quick, direct method for the determination of activation energy from thermogravimetry data. J. Polym. Sci., Part B: Polym. Phys., v.4, p.323-328, 1996.

GOSSELIN, P.M.; THIBERT, R.; PREDA, M.; MCMULLEN, J.N. Polymorphic properties of micronized carbamazepine produced by RESS. Int. J. Pharm., v.252, p.225-233, 2003.

GRZESIAK, A.L.; LANG, M.; KIM, K.; MATZGER, J.A. Comparison of the four anhydrous polymorphs of carbamazepine and crystal structure of Form I. J. Pharm. Sci., v.92, p.2260-2271, 2003.

GUINESI, L.S.; RIBEIRO, C.A.; CRESPI, M.S.; SANTOS, A.F.; CAPELA, M.V. Titanium (IV)-EDTA complex. $J$. Therm. Anal. Calorim., v.85, p.301-307, 2006. 
HAN, J.; SURYANARAYANAN, R. Applications of pressure differential scanning calorimetry in the study of pharmaceutical hydrates. I. Carbamazepine dihydrate. Int. J. Pharm., v.157, p.209-218, 1997.

JAVADZADEH, Y.; MOHAMMADI, A.; KHOEI N.S.; NOKHODCHI, A. Improvement of physicomechanical properties of carbamazepine by recrystallization at different pH values. Acta Pharm., v.59, p.187-197, 2009.

KOBAYASHI, Y.; ITO, S.; ITAI, S.; YAMAMOTO, K. Physicochemical properties and bioavailability of carbamazepine polymorphs and dihydrate. Int. J. Pharm., v.193, p.137-146, 2000.

KRAHN, F.U.; MIELCK, J.B. Relations between several polymorphic forms and the dihydrate of carbamazepine. Pharm. Acta Helv., v.62, p.247-254, 1987.

KRONGAUZ, V.V.; LING, M.T.K.; WOO, L.; PUROHIT, U. Kinetics of dihydro-dibenz $[b, f]$ azepine derivates sublimation. Thermochim. Acta, v.457, p.35-40, 2007.

LIU, W.; DANG, L.; BLACK, S.; WEI, H. Solubility of carbamazepine (Form III) in different solvents from (275 to 343) K. J. Chem. Eng. Data, v.53, p.511-521, 2008.

LIU, W.; DANG, L.; WEI, H. Thermal, phase transition, and thermal kinetics studies of carbamazepine. J. Therm. Anal. Calorim., v.111, p.1999-2004, 2012.

LOWES, M.M.J.; CAIRA, M.R.; LOTTER, A.P.; VAN DER WATT, J.G. Physicochemical properties and X-ray structural studies of the trigonal polymorph of carbamazepine. $J$. Pharm. Sci., v.76, p.744-752, 1987.

McGREGOR, C.; SAUNDERS, M.H.; BUCKTON, G.; SAKLATVALA, R.D. The use of high-speed differential scanning calorimetry (Hyper-DSC ${ }^{\mathrm{TM}}$ ) to study the thermal properties of carbamazepine polymorphs. Thermochim. Acta, v.417, p.231-237, 2004.

McMAHON, L.E.; TIMMINS, P.; WILliANS, A.C.; YORK, P. Characterization of dehydrates prepared from carbamazepine polymorphs. J. Pharm. Sci., v.85, p.10641069, 1996.
O'MAHONY, M.A.; MAHER, A.; CROKER, D.M.; RASMUSON, A.C.; HODNETT, B.K. Examining solution and solid state composition for the solution-mediated polymorphic transformation of carbamazepine and piracetam. Cryst. Growth Des., v.12, p.1925-1932, 2012.

OMNIC. Version 8.0. [S.I]: Thermo fisher scientific Inc., 2008. 1 CD-ROM.

ONO, M.; TOZUKA, Y.; OGUCHI, T.; YAMAMURA, S.; YAMAMOTO, K. Effects of dehydration temperature on water vapor adsorption and dissolution behavior of carbamazepine. Int. J. Pharm., v.239, p.1-12, 2002.

OZAWA, T. Kinetic analysis of derivate curves in thermal analysis. J. Therm. Anal., v.2, p.301-324, 1970.

QU, H.; LOUHI-KULTANEN, M.; KALLAS, J. Solubility and stability of anhydrate/hydrate in solvent mixtures. Int. J. Pharm., v.321, p.101-107, 2006.

ROSE, F.C.; JOHNSON, F.N. Carbamazepine in the treatment of non-seizure disorders: trigeminal neuralgia, other painful disorders, and affective disorders. Rev. Contemp. Pharmaco, v.8, p.123, 1997.

RUSTICHELLI, C.; GAMBERINI, G.; FERIOLI, V.; GAMBERINI, M.C.; FICARRA, R.; TOMMASINI, S. Solid-state study of polymorphic drugs: carbamazepine. $J$. Pharm. Biomed. Anal., v.23, p.41-54, 2000.

SOLON, L.G.S.; OLIVEIRA, A.I.M.; GUERRA, G.C.B.; SOARES, L.A.L.; ARAÚJO, A.A. Determination of carbamazepine in pharmaceutical formulations. Braz. J. Pharm. Sci., v.46, p.509-513, 2010.

VYAZOVKIN, S.; BURNHAM A.K.; CRIADO, J.M.; PÉREZMAQUEDA, L.A.; POPESCU, C.; SBIRRAZZUOLI, N. ICTAC Kinetics Committee recommendations for performing kinetic computations on thermal analysis data. Thermochim. Acta, v.520, p.1-19, 2011.

XU, C.; ZOU, M.; LIU, Y.; REN, J.; TIAN, Y.; YAN, J.; WANG, Y.; CHENG, G. Pharmacokinetics of carbamazepine polymorphs and dihydrate in rats, related to dogs and humans. Arch. Pharmacol. Res., v.34, p.1973-1982, 2011.

Received for publication on $15^{\text {th }}$ October 2013 Accepted for publication on $09^{\text {th }}$ May 2014 